\title{
A Learning Model of Group Discussion Accompaniment of Presentation Task in the Classroom
}

\author{
Bagus Kisworo \\ Department of Nonformal Education \\ Universitas Negeri Semarang Semarang, Indonesia \\ bagus.kisworo@mail.unnes.ac.id
}

\author{
Yudi Siswanto \\ Department of Nonformal Education \\ Universitas Negeri Semarang Semarang, Indonesia \\ yudie.sw@gmail.com
}

\begin{abstract}
This research was based on students' problems in presenting the results of learning material discussion in the classroom, this study was aimed to formulate a way to present the results of their discussions in front of the class as well. The research method used was Research and Development method (R\&D). It is a method which is used to produce a product and test its effectivenes in accordance with the objectives of development. The product produced from this research and development was a prototype of the group discussion accompaniment model. The method used were descriptive and evaluative methods. Descriptive method was used to collect the conditions that exist in the field. Evaluative method was used to evaluate the appropriateness of the group discussion accompaniment of presentation tasks in the classroom. The data analysis results were the guidelines of the group discussion accompaniment of presentation tasks model in the classroom. The final confirmation showed that the group discussion accompaniment model was effective in developing the potentials and increasing students' independence.
\end{abstract}

Keywords: learning model, accompaniment, group discussion

\section{INTRODUCTION}

Model is defined as a conceptual framework that is used as a guideline in doing activities. It can also be understood as a representation of a system that is considered to represent the actual system [1][2][3]. Model is a narrative description to describe the procedure or steps in achieving a specific goal, and these steps can be used to measure success or failure in achieving it [4]. According to Haryati, model is a design that illustrates the operation of a system in the form of a chart that connects the charts or stages through specific steps and can be used to measure success for the purpose of developing a valid decision [5]. Educational needs require the concept of learning models to achieve the objectives that are suitable for the era of industrial revolution 4.0.

Gunter [6] defines an instructional model as a step-by-step procedure that leads to a specific learning outcomes. In addition, the learning model is a plan or pattern that can be used to arrange a curriculum (long-term learning plan), design learning materials, and guide learning in the classroom or other [7].

Accompaniment in teaching and learning process means accompanying students in completing tasks given by the teacher in order to help them understand, conducting and drawing conclusion from the materials provided by the teacher so that the students feel guided and directed as the expected learning goals in an atmosphere that is fun and free from stress. Accompaniment is an activity conducted and can be known as coaching, teaching, directing groups that are more connotative to mastering, managing, and controlling [8]. Accompaniment is more meaningful in togetherness or equality where the position between the two (the companion and the person being accompanied) is equal, so that there is no term for superior or inferior. This implies that the role of the companion is only providing alternatives, consultative advices and assistances, and not on decision making, managing, and controlling [9].

Based on the initial observation activities, the strategy of creating discussion groups to present in the classroom is often used by most educators. One promising context for digital ink is university classroom, where instructors increasingly rely on digital slide projections [10]. This strategy is said effective in fulfilling the learning process activities where the students' involvement and independence in the learning process will increasingly appear. However, this strategy is not well supported by the availability of facilities and even the lecturers ${ }^{6}$ involvement of in preparing discussion groups which then result in inadequate classroom discussion 
activities. Recommendations for making lectures more effective, according to the principles described above and considering three moments: Preparation, delivery and finalization of the lecture. [11]

Some of the problems that appear in group discussions in the classroom were presented less interestingly by the group in charge. They were lack of mastery of the materials that made them not ready with questions that are related, the materials delivery that did not lead to substance, the interaction built was rigid, there was no distribution of each task for each individual in the group when presenting the materials, even if there was a task, each individual couldnot understand or interpret his/her roles, and the language communication used was not proper.

\section{METHOD}

The research method used was research and development $(\mathrm{R} \& \mathrm{D})$. This is a method used to create products and to test the effectiveness of the product in accordance with the objectives of the development. The product produced from this research and development was a prototype model of learning through group discussion accompaniment of presentation tasks in the classroom. The method used was descriptive and evaluative method. Descriptive method was used to collect conditions in the field. Evaluative methods was used to learn the feasibility of learning models through group discussion accompaniment of presentation tasks in the classroom which were realized in the form of activities and learning planning guideline. Through product evaluation and experimental process, it was expected to gain information about the advantages and disadvantages of the product being developed. In developing the learning model through group discussion accompaniment, it was conducted by implementing the development model procedure from Borg and Gall that had been modified.

The research and development procedure according to Borg \& Gall [12] basically consists of two main objectives, they are: (a) developing a product, and (b) testing the effectiveness of the product in achieving its objectives. Procedures or work steps in this study include; a) preliminary research, b) design making, c) production of activities and learning guideline, and d) field test product.

The procedures for developing learning models through discussion group accompaniment of presentation tasks are as follows:

\section{A. Preliminary Research}

The first step was investigation and preliminary data collection. This step was meant to obtain data about field conditions related the presentation task. From this preliminary research, various potentials and problems faced in the process of presentation activities in the classroom were identified. The data were collected through: (a) knowledge about presentation techniques in class, (b) mastery of materials in doing presentation, (c) readiness in answering questions, (d) interaction built, (e) tasks of each individuals in group presentation, (f) literature study.

B. Development Design Planning

The equations are an exception to the prescribed specifications of this template. You will need to determine whether or not your equation should be typed using either the Times New Roman or the Symbol font (please no other font). To create multileveled equations, it may be necessary to treat the equation as a graphic and insert it into the text after your paper is styled.

C. Production Process

The process of producing activities guideline began with designing the manuscript, preparing the accompaniment guideline, and being ended with validation.

D. Field Test and Evaluation of the Product

To obtain the feasibility of the learning model of group discussion accompaniment of presentation task in the classroom, it is important to have field test and evaluation. Field test and evaluation of the product were done through three stages, those are: (a) validation of the material expert and the instructional material expert/ activities guideline. The product being developed must be validated before being tested to the students. This field test was important to do in order to make sure that the initial product developed was feasible to be tested to the students and to avoid any significant problems. (b) Field test, this test aimed to determine whether the product produced was feasible to use. The product was tested to 10 groups who were given the presentation task materials in the classroom in order to get a broader response related to the model developed. After the field test, the students were given a questionnaire containing their responses related to the learning model of the group discussion accompaniment of presentation task in the classroom and after that, analysis and product revision were done based on the results of the field test.

\section{E. Completion}

Based on the information obtained through the field test, the product was analyzed and then improved and perfected so that the accompaniment guideline will be obtained in the group discussion of task presentation in the classroom. So, it can be used and distributed to users.

F. Data Collection Techniques

The collected data in this development research included initial condition data, material expert assessment data, expert assessment, student 
assessment, and field test. Data collections techniques used were observation / interviews, and questionnaires. Techniques applied were (a) Observation and interview techniques were used to collect initial condition data about the learning process and an activity guideline existence as a guide for the teachers and the students. (b) Questionnaire technique was used to collect the activity and learning guide feasibility assessment data according to the opinion of experts and students.

\section{G. Data Analysis Techniques}

The data which were through preliminary research, expert assessment, limited field test, and effectiveness tests were then analyzed and described. The data obtained were qualitative and quantitative data. (a) Initial condition data analysis, which were the activity guides and the conditions of students' presentation processes. (b) Product suitability data analysis, suitability data of learning models guide product which was developed according to the experts and students opinion. (c) The effectiveness data analysis, the data which assessed the effectiveness of activity and learning guides was analyzed in quantitative statistics using the percentage of success in practicing students' accompaniment guide and the student responses to teachers' accompaniment. To measure the product effectiveness, it was done by giving responses and practice to the students. The assessment of practice was based on the accuracy in carrying out the stages in establishing study groups, the material mastery, the group assignments division, the understanding of each individual task in the group, the use of standard language, the creation of conducive interactions, the materials and tools preparation, the media preparation, and team work. The total score was a combination and $40+60=100$. The product was said to be reliable if $75 \%$ of students get a score of more than or equal to 75 .

\section{RESULT AND DISCUSSION}

The field test data of the learning model development of group discussion accompaniment of presentation task in the classroom is presented in the following table:

Table I

The Field Test Data For Every Aspect Of The Material Experts Guideline

\begin{tabular}{|l|l|l|l|}
\hline No & $\begin{array}{c}\text { Aspect of } \\
\text { Indicator }\end{array}$ & Score & Category \\
\hline 1 & Guide & 4.00 & Very good \\
\hline 2 & Objective & 4.10 & Very good \\
\hline 3 & Material & 3.70 & Good \\
\hline 4 & Performance & 4.21 & Very good \\
\hline
\end{tabular}

The average total of all field test by the experts was 4.00. In five scale tables, the value was included in the category of "Very Good", this meant that the learning model guideline development of group discussion accompaniment of presentation tasks in the classroom was very good.

The field tests were based on the input from the expert reviews, and then the next step was to carry out the field tests which implemented to 10 groups who were given the task of presenting material in the classroom. The results of the field tests can be seen in the following table:

TABLE II

The AVerage Score OF Field TeSts

\begin{tabular}{|c|c|c|c|}
\hline No & $\begin{array}{c}\text { Aspect of } \\
\text { Indicator }\end{array}$ & Score & Category \\
\hline 1 & Physical guide & 4.1 & Very good \\
\hline 2 & Objective & 4.10 & Very good \\
\hline 3 & $\begin{array}{c}\text { Material } \\
\text { description }\end{array}$ & 3.75 & Good \\
\hline 4 & Performance & 4.21 & Very good \\
\hline
\end{tabular}

Based on the table, it could be concluded that the average score of the physical guide aspects was 4.1 which category was very good, the objective aspect was 4.10 which the category was very good, the average score for the material description aspect was 3.75 which was included in the good category, and the average score of the performance aspect was 4.2 which category was very good. In addition, the data obtained through this field test was conducted to obtain information about the advantage of the guide in improving the ability to present a discussion material in the classroom, according to the results of observations and practical tests; they were obtained information that most students have understood the contents of the guide well.

The learning model development of group discussion accompaniment of presentation tasks in the classroom was a means and gave clear directions to the students to develop their ability to present the material in the classroom, so that the discussion would go well. The guideline could also increase the students' participation in the learning process. The models developed were from the collection of initial condition data in the classroom to the establishment of guidance draft and design. The guideline was also a guide for teachers in carrying out the students accompaniment to do a presentation in the classroom. The use of a guidebook would be very beneficial for the teachers and students. The handbook clarified how the accompaniment technical was carried out by a teacher and how a good presentation by students was, then with the guideline, the students were more motivated to learn and improved their selfcompetence and provided an interesting learning experience. 
The establishment of the learning model guideline of group discussion accompaniment in the classroom was an answer for students who have difficulty in learning, especially in practicing their ability to self-actualize in front of the class, the guideline could also be used by the teacher as part of a learning strategy and by students to learn independently. Thus, it concluded that the learning model guideline of group discussion accompaniment of presentation tasks in the classroom in the field tests has met the feasible used category. Learning is an interactive process which involved active participation from both the teacher and students in the classroom. An understanding on the behavior of the students in the classroom will help the teacher identify the passive students and plan ways to encourage them to actively participate in the classroom. Both teacher and students must actively engage in the classroom to create a more fun and meaningful learning experiences [13].

This was in accordance with the principles of learning according to Slameto [14] (a) Based on the prerequisites needed for learning: students must always participate actively in every learning process they experience, increase the learning interest, and guide students in learning in order to achieve instructional goals. (b) According to the nature of learning: learning is a continuous process. Therefore, its implementation must be carried out step by step. (c) Appropriate material/substance to be studied: students will more easily capture the learning if the material is presented simply. and (d) Requirements for the learning success: supporting facilities in the learning process will make students feel quite when they are studying.

\section{CONCLUSION}

The feasibility of the learning model guideline of group discussion accompaniment of presentation tasks in the classroom is very helpful for teachers and students because it became a guide for teachers and part of the strategy in the learning process. The direction of student learning was increasingly clear because the guideline is a means for them in learning so that they could be independent and able to develop their potential through the presentation in front of the class. The group discussion accompaniment model provided new discourse for teachers to develop more effective learning models..

\section{ACKNOWLEDGMENT}

We would like to express our gratitude to Prof. Dr. Fathur Rokhman, M. Hum, Rector of Universitas Negeri Semarang and Dr. Suwito Eko
Pramono, M.Pd, Chairman of the Institute for Research and Community Service who has provided opportunities for researchers to conduct scientific studies in Nonformal Education with funding from DIPA Universitas Negeri Semarang in 2019.

\section{REFERENCES}

[1] A. M. Law and D. W. Kelton, McGraw-Hili Series in Industrial Engineering and Management Science' Consulting Editor Huchingson: New Horizons for Human Factors in Design. 1991.

[2] S. Syaiful, Konsep dan Makna Pembelajaran. Bandung: CV. Alvabeta, 2005.

[3] P. Sudarman, Belajar efektif di perguruan tinggi. 2004.

[4] M.-Y. Yang, M. You, and F.-C. Chen, "Competencies and qualifications for industrial design jobs: implications for design practice, education, and student career guidance," Des. Stud., vol. 26, no. 2, pp. 155-189, Mar. 2005.

[5] S. Haryati, "Research And Development (R\&D) Sebagai Salah Satu Model Penelitian dalam Bidang Pendidikan," Res. Dev. Sebagai Salah Satu Model Penelit. Dalam Bid. Pendidik., vol. 37, pp. 11-26, 2012.

[6] J. H. Gunter, M. A., Estes, T. H., \& Schwab, Intruction: A models approach. Bostan: Allyn and Bacon, 1990

[7] M. Joyce, Bruce and Weil, Models of Teaching (Second Edition). Englewood Cliffs, New Jersey: Prentice-Hall, Inc, 1980.

[8] L. Fajri and K. Martini, "Upaya peningkatan proses dan hasil belajar kimia materi koloid melalui pembelajaran kooperatif tipe TGT (Teams Games Tournament) dilengkapi dengan teka-teki," J. Pendidik. Kim., vol. 1, no. 1, pp. 89-96, 2012.

[9] R. Nugrahani and J. S. Rupa, "Media Pembelajaran Berbasis Visual Berbentuk Permainan Ular Tangga Untuk Meningkatkan Kualitas Belajar Mengajar Di Sekolah Dasar," Lembaran Ilmu Kependidikan, vol. 36, no. 1, pp. 35-44, 2007.

[10] R. J. Anderson, C. Hoyer, S. A. Wolfman, and R. Anderson, "A study of digital ink in lecture presentation," in Conference on Human Factors in Computing Systems - Proceedings, 2004, pp. 567574.

[11] A. G. Palis and P. A. Quiros, "Adult learning principles and presentation pearls," Middle East Afr. J. Ophthalmol., vol. 21, no. 2, pp. 114-122, 2014.

[12] W. R. Borg and M. D. Gall, Educational Research: An Introduction. 2003

[13] M. Y. Abdullah, N. R. A. Bakar, and M. H. Mahbob, "The Dynamics of Student Participation in Classroom: Observation on Level and forms of Participation," Procedia - Soc. Behav. Sci., vol. 59, pp. 61-70, 2012.

[14] Slameto, Belajar dan Faktor-faktor yang Mempengaruhinya. Jakarta: Asdi Mahasatya, 2003 